\begin{tabular}{|l|l|l|}
\hline \multicolumn{2}{|c|}{ PublisherInfo } \\
\hline \hline PublisherName & $:$ & Palgrave Macmillan UK \\
\hline \hline PublisherLocation & $:$ & London \\
\hline \hline PublisherImprintName & $:$ & Palgrave Macmillan \\
\hline \hline
\end{tabular}

\title{
The effect of bonuses on earnings growth in 2007
}

\begin{tabular}{||l|l|l||}
\hline \multicolumn{2}{|c|}{ ArticleInfo } \\
\hline \hline ArticleDOI & $:$ & $10.1057 /$ palgrave.elmr.1410156 \\
\hline \hline ArticleCategory & $:$ & Feature \\
\hline \hline ArticleFirstPage & $:$ & 43 \\
\hline \hline ArticleLastPage & $:$ & 45 \\
\hline \hline & & RegistrationDate $:$ 2007-10-19 \\
ArticleHistory & $:$ & OnlineDate $\quad: 2007-10-19$ \\
\hline \hline ArticleCopyright & $:$ & Crown copyright2007 \\
\hline \hline
\end{tabular}




\section{Harry Duff, ${ }^{\text {Aff1 }}$}

\section{Examines the effect of bonus payments as a major influence on pay growth in the Average Earnings Index.}

This article examines the effect of bonus payments on the Average Earnings Index (AEI). The AEI is the National Statistic measure of short-term earnings growth. A separate article published in last month's Economic \& Labour Market Review describes the relationship between the AEI and the experimental series Average Weekly Earnings. Bonus payments are a major influence on pay growth as measured by the AEI. Changes in their level or the month in which they are paid can have a significant effect on growth rates. The majority of large bonuses are generally paid in the period December to April each year, mainly, but not exclusively, in the financial services sector. The article looks at the impact of bonuses on earnings growth during the period December 2006 to April 2007.

Misc

The Full Text of this article can be found on the National Statistics website (http://www.statistics.gov.uk/elmr/10_07/downloads/elmr_oct07_duff.pdf). 